\title{
Effects of light fractionation and different fluence rates on photodynamic therapy with 5-aminolaevulinic acid in vivo
}

\author{
P Babilas', V Schacht ${ }^{1,3}$, G Liebsch ${ }^{2,4}$, OS Wolfbeis², M Landthaler', R-M Szeimies', and C Abels,, \\ 'Department of Dermatology, University of Regensburg, Franz-Josef-Strauss-Allee II, 93042 Regensburg, Germany; ${ }^{2}$ Institute of Analytical Chemistry, \\ Chemo- and Biosensors, University of Regensburg, Franz-Josef-Strauss-Allee II, 93042 Regensburg, Germany
}

To improve efficacy of photodynamic therapy (PDT) with intravenously administered 5-aminolaevulinic acid (ALA) fractionating the light dose or reducing the light intensity may be a possibility. Therefore, Syrian Golden hamsters were fitted with dorsal skinfold chambers containing an amelanotic melanoma $(n=26)$. PDT was performed $\left(100 \mathrm{~mW} \mathrm{~cm}^{-2}, 100 \mathrm{~J} \mathrm{~cm}^{-2}\right.$, continuously or fractionated, and $25 \mathrm{~mW} \mathrm{~cm}^{-2}, 100 \mathrm{~cm}^{-2}$; continuously or fractionated) using an incoherent light source following i.v. application of ALA. Following fractionated irradiation, the light was paused after $20 \mathrm{~J} \mathrm{~cm}^{-2}$ for $15 \mathrm{~min}$. Prior to and up to $24 \mathrm{~h}$ after PDT tissue, $p \mathrm{O}_{2}$ was measured using luminescence lifetime imaging. The efficacy was evaluated by measuring the tumour volume of amelanotic melanoma cells grown subcutaneously in the back of Syrian Golden hamsters $(n=36)$. Only high-dose PDT resulted in a significant decrease of $\mathrm{pO}_{2}$. Irrespective of the mode of irradiation only high-dose PDT induced complete remission of all tumours (I 3 out of 13). It could be shown that low-dose PDT failed to induce a significant decrease of $\mathrm{pO}_{2}$. No significant effect of fractionated irradiation was shown regarding the therapeutic efficacy 28 days after PDT. Thus performing a fractionated PDT with ALA or reducing the light intensity seems not to be successful in clinical PDT according to the present data. British Journal of Cancer (2003) 88, I 462 - |469. doi: I0.1038/sj.bjc.66009 I0 www.bjcancer.com (C) 2003 Cancer Research UK

Keywords: amelanotic melanoma; protoporphyrin IX; oxygen; microcirculation; tumour

Photodynamic therapy (PDT) involves the generation of reactive oxygen species after activation of a photosensitiser by light (Pass, 1993; van Hillegersberg et al, 1994; Dougherty et al, 1998). Since the only clinically approved systemic photosensitiser, Photofrin ${ }^{\circledR}$, causes generalised cutaneous photosensitivity up to 4-6 weeks following PDT, 5-aminolaevulinic acid (ALA) has raised hope as a promising photosensitiser for PDT (Peng et al, 1997). The endogenous photosensitiser ALA is a haem precursor and induces the synthesis of porphyrins (protoporphyrin IX, PpIX) in mitochondria-containing cells (Williams, 1990). A selectivity of ALA-induced porphyrins is described in neoplastic tissue (Abels et al, 1994; Ackermann et al, 1998; Langer et al, 1999) as well as in malignant cells (Rittenhouse-Diakun et al, 1995) and provides the basis for clinical use of ALA-based photodynamic therapy (Mlkvy et al, 1995) and diagnosis (Kriegmair et al, 1995). ALA is water soluble and can therefore be administered either systemically (Grant et al, 1993) or topically (Szeimies et al, 1994).

However, PDT with intravenously administered ALA failed to be as successful as PDT with Photofrin ${ }^{\mathbb{R}}$ in an amelanotic melanoma

*Correspondence: Dr C Abels;

E-mail: christoph.abels@klinik.uni-regensburg.de

${ }^{3}$ Current address: CBRC/Department of Dermatology, Massachusetts General Hospital, Harvard Medical School, Charlestown, MA 02129, USA;

${ }^{4}$ Current address: BIOCAM GmbH, Friedenstraße 30, 93053 Regensburg, Germany.

Received 19 December 2002; revised 20 February 2003; accepted 21 February 2003
(Abels et al, 1997a). To improve efficacy of ALA - PDT fractionating the light dose or reducing the light intensity might be a possibility (Gibson et al, 1990; Messmann et al, 1995; de Bruijn et al, 1999; Iinuma et al, 1999). Splitting the light dose into fractions by pausing the light source for a certain time is supposed to enable reoxygenation of the irradiated tissue and may increase the generation of singlet oxygen thus enhancing PDT (Hua et al, 1995; Robinson et al, 2000; Pogue et al, 2001). In addition, new PpIX might be formed during the irradiation break further contributing to the generation of reactive oxygen species during the second irradiation turn (de Bruijn et al, 1999; Robinson et al, 2000). A low-dose PDT is supposed to result in a slower oxygen consumption and therefore allows oxygen to be continuously supplied compared with high-dose PDT (Hua et al, 1995; Robinson et al, 2000; Pogue et al, 2001). Therefore, the oxygen concentration, for example, partial oxygen pressure $\left(p \mathrm{O}_{2}\right)$, in the tissue is critical and the measurement of tissue oxygenation is of great importance. It is well known that the $p \mathrm{O}_{2}$ in normal tissue is different from the $\mathrm{pO}_{2}$ in tumour tissue. While in normal tissue, the median $\mathrm{pO}_{2}$ values range from 24 to $66 \mathrm{mmHg}$, the value in the respective malignant tissue is $\leqslant 20 \mathrm{mmHg}$ (Vaupel et al, 1989).

In this study, the $p \mathrm{O}_{2}$ in tumour and surrounding tissue was measured to evaluate the therapeutic effect of different dosimetric protocols for ALA-PDT in vivo. The technique of measuring the tissue $\mathrm{pO}_{2}$ by planar optical sensors and luminescence lifetime imaging (Liebsch et al, 2000, 2001) allows a spatially highly resolved mapping of two-dimensional $p \mathrm{O}_{2}$-distribution within the chamber tissue in a noninvasive way. In addition, the $\mathrm{pO}_{2-}$ measurements were then correlated with tumour growth after PDT with the respective dosimetric protocol. 


\section{MATERIALS AND METHODS}

\section{Animal and tumour model}

For experiments male Syrian Golden hamsters of 30-40 g body weight (b.w.) (Breeder: Fa. Harlan-Winkelmann GmbH, Borchen, Germany) and cells of the amelanotic hamster melanoma (A-Mel3) were used (Fortner et al, 1961). The animals were housed in single cages and had free access to food and water.

For the $p \mathrm{O}_{2}$-measurements, the animals were fitted with titanium dorsal skinfold chambers obtained from the Institute for Surgical Research, Munich, Germany $(n=26)$. They tolerated the chambers well and showed no signs of discomfort. Amelanotic melanoma cells (A-Mel-3) (Fortner et al, 1961) were implanted (approximately $2 \times 10^{5} \mathrm{~A}-\mathrm{Mel}-3$ cells in suspension) in the dorsal skinfold chamber $48 \mathrm{~h}$ after surgical preparation of the chambers exhibiting an intact microcirculation (for details see, Endrich et al, 1980). At 5 days after tumour cell implantation, permanent indwelling catheters (PE-10, $0.4 \mathrm{~mm}$ i.d., Portex, Hythe, UK) were inserted into the right carotid artery and right external jugular vein under ketamine/xylazine anesthesia (100 and $8 \mathrm{mg} \mathrm{kg}^{-1}$ b.w. i.p.).

To evaluate the impact of the different irradiation protocols on tumour growth $5 \times 10^{6}$ amelanotic melanoma cells were implanted subcutaneously in the shaved and chemically depilated (Pilca med, Olivin, Hamburg, Germany) dorsal skin of the hamsters $(n=36)$ under ketamine/xylazine anaesthesia (100 and $8 \mathrm{mg} \mathrm{kg}^{-1}$ b.w. i.p.) (Dellian et al, 1995; Abels et al, 1997a,b). The take rate of the tumours following implantation was $100 \%$. After 4 days of growth, the tumours had grown to a mean volume of approximately $100 \mathrm{~mm}^{3}$ (mean tumour volume, $100 \pm 7.5 \mathrm{~mm}^{3}$ ). Permanent indwelling catheters (PE-10, $0.4 \mathrm{~mm}$ i.d., Portex, Hythe, UK) were inserted into right external jugular vein under ketamine/xylazine anaesthesia (100 and $8 \mathrm{mg} \mathrm{kg}^{-1}$ b.w. i.p.) and removed after ALA application.

All experiments have been carried out with ethical committee approval and meet the standards required by the UKCCCR guidelines (Workman et al, 1988). In addition, each procedure was approved by the regional authorities according to the German animal care regulations, which are in accordance with the international guidelines of animal care and use in scientific experiments (AZ 621 2531.1-28/00).

\section{Preparation and administration of ALA}

5-Aminolaevulinic acid as a hydrochloride salt (MW 168) was obtained from Merck (Darmstadt, Germany), dissolved in $\mathrm{NaCl}$ ( $\mathrm{pH}$ 6.5) at a concentration of $100 \mathrm{mg} \mathrm{ml}^{-1}$ and used immediately. 5-Aminolaevulinic acid was administered intravenously in a dose of $500 \mathrm{mg} \mathrm{kg}^{-1}$ b.w. according to previous experiments (Abels et al, 1994, 1997a; Szeimies et al, 1995). The conscious animals did not show any signs of discomfort during injection of the ALA-solution as previously reported by Edwards et al (1984).

\section{$\mathrm{pO}_{2}$-Measurement}

The $\mathrm{PO}_{2}$-measurement was performed using luminescence lifetime imaging of a luminescent oxygen indicator, which is immobilised in an oxygen permeable sensor foil (for details see, Liebsch et al, $2000,2001)$. The indicator is capable of translating the respective oxygen partial pressure into a light signal. The optical $p \mathrm{O}_{2}$-sensor foil (platinum(II)-octaethyl-porphyrin in polystyrene) was calibrated in vitro and attached to the cover glass of the chamber preparation in direct contact with the surface of the chamber tissue. Thus, the $\mathrm{pO}_{2}$ of the tissue surface can be measured at any time noninvasively. PDT can be performed through the transparent sensor foil because irradiation does not damage the luminescent oxygen sensor (data not shown). A transillumination image can be generated and overlaid with the respective $\mathrm{pO}_{2}$ image.
The hamsters were fixed in a Perspex tube placed on a motorised, computer-controlled stage (Spindler \& Hoyer GmbH, Göttingen, Germany). The temperature of the dorsal skinfold chamber was kept constant by a custom-made water bath at $29^{\circ} \mathrm{C}$. For intravital microscopy (IVM), a Zeiss Axiotech Vario $100 \mathrm{HD}$ microscope was modified for time-resolved imaging of luminescent sensor foils. A fast gateable CCD-camera (SensiMod, PCO, Kehlheim, Germany) and a pulsed light source were mounted to the microscope. Green excitation light $(535 \mathrm{~nm})$ was reflected by a dichroic mirror (Deep Orange, O590, Balzers) to the $\mathrm{pO}_{2}$-sensor foil of the observation chamber of the dorsal skinfold chamber. The sensor luminescence was optically filtered with a long-pass filter (RG630, Fa. Schott, Mainz, Germany) and detected via rapid lifetime determination (RLD) (for details see, Liebsch et al, 2000, 2001).

Prior to PDT, a transillumination image and a $p \mathrm{O}_{2}$-image were generated. At $15 \mathrm{~min}, 1,2$ and $24 \mathrm{~h}$ after PDT and, in case of fractionated irradiation, in the irradiation break $\mathrm{pO}_{2}$-measurements were performed.

\section{Photodynamic therapy}

For light irradiation the animals wearing a transparent dorsal skinfold chamber were immobilised in a Perspex tube. The animals were randomly assigned to the different groups according to the different protocols: control (I); high-dose PDT $\left(100 \mathrm{~mW} \mathrm{~cm}^{-2}\right.$, $100 \mathrm{~J} \mathrm{~cm}^{-2}$ ), continuous irradiation (II); high-dose PDT $\left(100 \mathrm{~mW} \mathrm{~cm}^{-2}, 100 \mathrm{~J} \mathrm{~cm}^{-2}\right)$, fractionated irradiation (III); lowdose PDT $\left(25 \mathrm{~mW} \mathrm{~cm}^{-2}, 100 \mathrm{~J} \mathrm{~cm}^{-2}\right)$, continuous irradiation (IV); low-dose PDT $\left(25 \mathrm{~mW} \mathrm{~cm}^{-2}, 100 \mathrm{~J} \mathrm{~cm}^{-2}\right)$, fractionated irradiation (V). At the time of highest fluorescence intensity, $150 \mathrm{~min}$ after intravenous ALA application $\left(500 \mathrm{mg} \mathrm{kg}^{-1}\right.$ b.w), the irradiation was performed with an incoherent light source $\left(\lambda_{\mathrm{em}}=580-\right.$ $740 \mathrm{~nm}$, PDT 1200, Waldmann, Germany) as published previously (Abels et al, 1994, 1997a; Szeimies et al, 1995). The light dose of $100 \mathrm{~J} \mathrm{~cm}^{-2}$ was kept constant in all groups. Following the fractionated irradiation, the light was paused after a light dose of $20 \mathrm{~J} \mathrm{~cm}^{-2}$ for a break of $15 \mathrm{~min}$ before the remaining $80 \mathrm{~J} \mathrm{~cm}^{-2}$ was applied. The total duration of PDT light treatment was $16.6 \mathrm{~min}$ using high-PDT-dose rates $\left(100 \mathrm{~mW} \mathrm{~cm}^{-2} ; 100 \mathrm{~J} \mathrm{~cm}^{-2}\right)$, respectively and $66.6 \mathrm{~min}$ using low-PDT-dose rates $\left(25 \mathrm{~mW} \mathrm{~cm}^{-2}\right.$; $100 \mathrm{~J} \mathrm{~cm}^{-2}$ ).

The animals bearing a solid subcutaneous tumour were placed in a Perspex tube for light treatment. The distance between the animal body and the tumour was increased by raising a skin flap bearing the tumour through a slit in the Perspex tube and fixing it along a plastic arch with three sutures. At $150 \mathrm{~min}$ after intravenous ALA application, irradiation was performed with the incoherent light source. The animals were again assigned to the different groups according to the protocol. In addition, a group with continuous irradiation $\left(25 \mathrm{~mW} \mathrm{~cm}^{-2}, 100 \mathrm{~J} \mathrm{~cm}^{-2}\right)$ but without ALA and a control group were performed. The tumour volume was measured throughout the complete observation period (28 days). The longer $(l)$ and the shorter $(w)$ perpendicular axes and the height $(h)$ of each tumour were measured with callipers prior to and after PDT at 2-3-day intervals over 28 days. Individual tumour volume was calculated using the formula $\mathrm{Clwh}$, where $C$ is an empirically determined correction factor of 0.873 (Tomayko and Reynolds, 1989; Weiss et al, 1990). Tumour response to PDT was classified as follows: complete remission (disappearance of all signs of tumour), partial remission (more than $50 \%$ decrease of the product of the two largest perpendicular tumour diameters for a minimum of 7 days), no changes (less than $50 \%$ decrease or less than $25 \%$ increase of the product of the two largest perpendicular tumour diameters for a minimum of 5 days or progression (more than $25 \%$ increase of the product of the two largest perpendicular tumour diameters) (Livingston and Carter, 1982). 


\section{Statistics}

For the graphics and statistical analysis of the data, ORIGIN ${ }^{\circledR}$ (Microcal, Northampton, MA, USA) or SigmaStat ${ }^{\circledR}$ was used. Results are expressed as the mean \pm standard error of the mean if not indicated otherwise. Differences were considered as significant if $P<0.05$.

\section{RESULTS}

\section{$\mathrm{pO}_{2}$ measurements}

Figure 1 shows oxygen maps of the dorsal skinfold chamber with an amelanotic melanoma prior to and after PDT $\left(100 \mathrm{~mW} \mathrm{~cm}^{-2}\right.$, $100 \mathrm{~J} \mathrm{~cm}^{-2}$, continuous irradiation) over the time (prior to, $30 \mathrm{~min}$, 2 and $24 \mathrm{~h}$ after PDT). The maps are pseudocolour images, the respective bar is inserted. Prior to PDT, the tumour region can be clearly differentiated from normal tissue because of the lower $\mathrm{pO}_{2}$ giving in blue colours. The $\mathrm{pO}_{2}$ is reduced after irradiation in tumour and surrounding tissue.

\section{High-dose PDT}

Figure 2 shows the $\mathrm{pO}_{2}$-measurements following high-dose PDT $\left(100 \mathrm{~mW} \mathrm{~cm}^{-2}, \quad 100 \mathrm{~J} \mathrm{~cm}^{-2}\right)$ irradiated either continuously (Figure 2A) or fractionated (Figure 2B).

Continuous irradiation induced a significant decrease of $\mathrm{OO}_{2}$ at any time in surrounding tissue and in tumour tissue: following PDT, $p \mathrm{O}_{2}$ decreased from $25.5 \pm 6.1 \mathrm{mmHg}$ (baseline) to $11.2 \pm 3.3$ $\mathrm{mmHg}(30 \mathrm{~min})$ followed by a slight increase to $14 \pm 4.5 \mathrm{mmHg}$ $(24 \mathrm{~h})$ in surrounding tissue. In tumour tissue, $\mathrm{pO}_{2}$ decreased from $12.7 \pm 6.4 \mathrm{mmHg}$ (baseline) to $7.6 \pm 3.2 \mathrm{mmHg}(30 \mathrm{~min})$ to remain at this level up to $24 \mathrm{~h}$ (Figure $2 \mathrm{~A}$ ).

The fractionated irradiation induced a decrease of $p \mathrm{O}_{2}$ in surrounding tissue and in tumour tissue as well (Figure 2B). Following PDT, $p \mathrm{O}_{2}$ decreased from $22.2 \pm 3.7 \mathrm{mmHg}$ (baseline) to $18.2 \pm 4.3 \mathrm{mmHg}$ (in the irradiation break), to $11.0 \pm 4.8 \mathrm{mmHg}$ $(15 \mathrm{~min})$ and to $7.3 \pm 3.2 \mathrm{mmHg}(2 \mathrm{~h})$ followed by a slight increase to $8.3 \pm 2.4 \mathrm{mmHg}(24 \mathrm{~h})$ in surrounding tissue. In tumour tissue, $\mathrm{pO}_{2}$ decreased from $8.2 \pm 1.7 \mathrm{mmHg}$ (baseline) to $6.3 \pm 2.2 \mathrm{mmHg}$ (in the irradiation break), and to $4.0 \pm 1.1 \mathrm{mmHg}(2 \mathrm{~h}$ ) followed by a slight increase to $5.4 \pm 1.8 \mathrm{mmHg}(24 \mathrm{~h})$ (Figure 2B).

In surrounding tissue, there was a difference detectable following high-dose PDT with continuous irradiation as compared to high-dose PDT with fractionated irradiation. The $p \mathrm{O}_{2}$ recovered $24 \mathrm{~h}$ following irradiation to $55 \%$ of the baseline-value in surrounding tissue following continuous irradiation, whereas following fractionated irradiation, the $\mathrm{OO}_{2}$ showed just a slight increase to $37 \%$ of the baseline-value $24 \mathrm{~h}$ following irradiation (Figure 2). In tumour tissue $\mathrm{pO}_{2}$ showed no significant difference following continuous or fractionated irradiation as the $p \mathrm{O}_{2}$ recovered $24 \mathrm{~h}$ following irradiation to $61 \%$ and to $66 \%$, respectively, of the baseline-value (Figure 2).

\section{Low-dose PDT}

Figure 3 shows the $\mathrm{pO}_{2}$-measurements following low-dose PDT $\left(25 \mathrm{~mW} \mathrm{~cm}^{-2}, \quad 100 \mathrm{~J} \mathrm{~cm}^{-2}\right)$ irradiated either continuously (Figure $3 \mathrm{~A}$ ) or fractionated (Figure $3 \mathrm{~B}$ ).
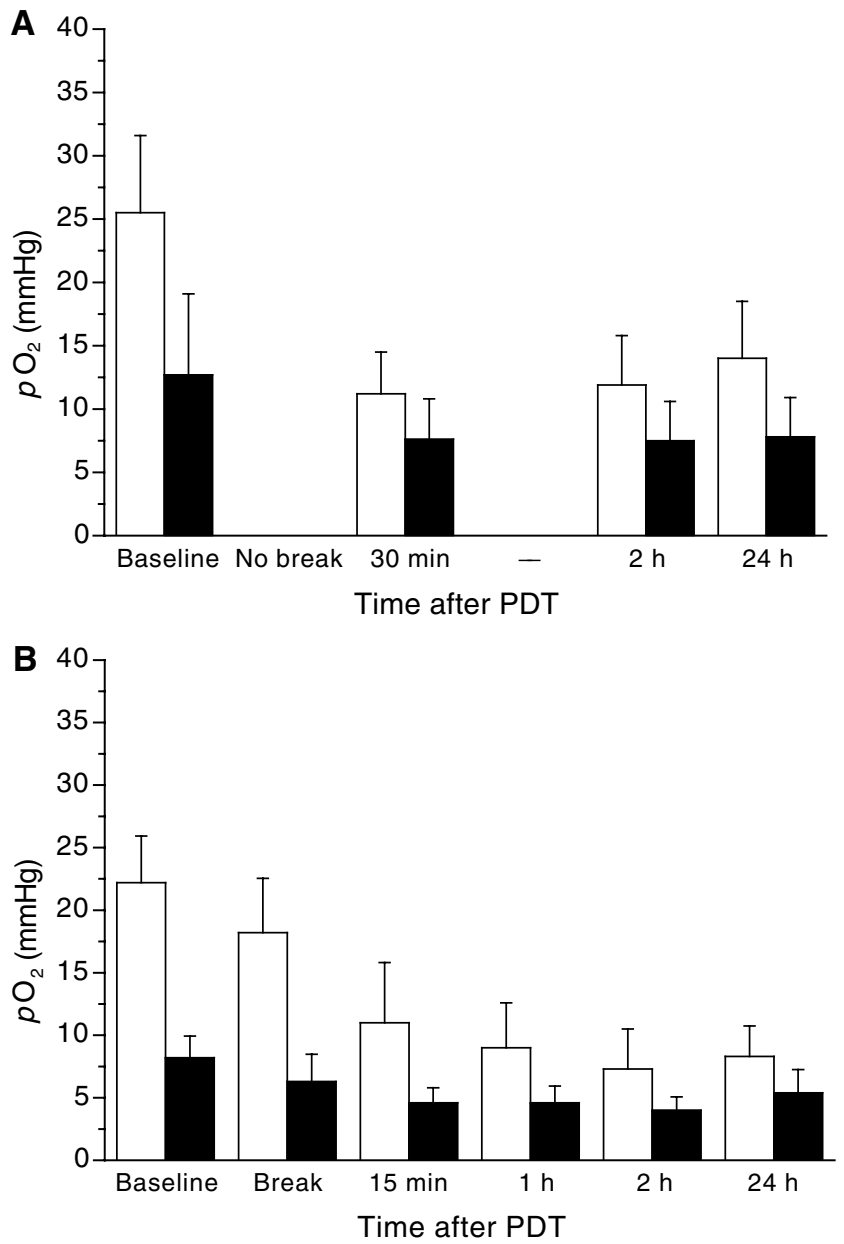

Figure $2 \mathrm{pO}_{2}$ was measured prior to and $15 \mathrm{~min}$, I h ( $\left.30 \mathrm{~min}\right), 2 \mathrm{~h}$ and $24 \mathrm{~h}$ (if fractionated additionally in the light pause) after high-dose PDT $\left(100 \mathrm{~mW} \mathrm{~cm}^{-2}, 100 \mathrm{~cm}^{-2}\right)$ in tumour tissue ( $)$ and in surrounding tissue $(\square)$ after continuous $(\mathbf{A}, n=7)$ or fractionated $(\mathbf{B}, n=6)$ irradiation. A decrease of $\mathrm{pO}_{2}$ in tumour and surrounding tissue is shown following high-dose PDT (median \pm s.e.m.).

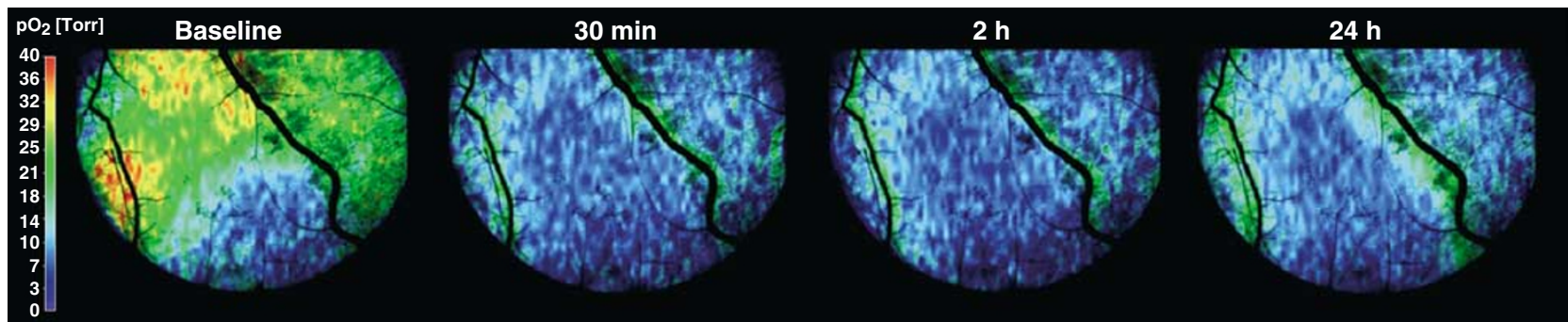

Figure I Oxygen maps of the dorsal skinfold chamber with A-Mel-3 tumour prior to and after PDT $\left(100 \mathrm{~mW} \mathrm{~cm}^{-2}, 100 \mid \mathrm{cm}^{-2}\right.$, continuous irradiation) over the time (prior to, $30 \mathrm{~min}, 2 \mathrm{~h}$ and $24 \mathrm{~h}$ after PDT). The maps are pseudocolour images, the colour bar gives information regarding the colour- $\mathrm{pO} \mathrm{O}_{2}$ relation. Prior to PDT, the tumour region can be clearly differentiated from normal tissue because of its blue colour due to the lower oxygen tension. The $\mathrm{pO}_{2}$ is reduced after irradiation in tumour and surrounding tissue. 

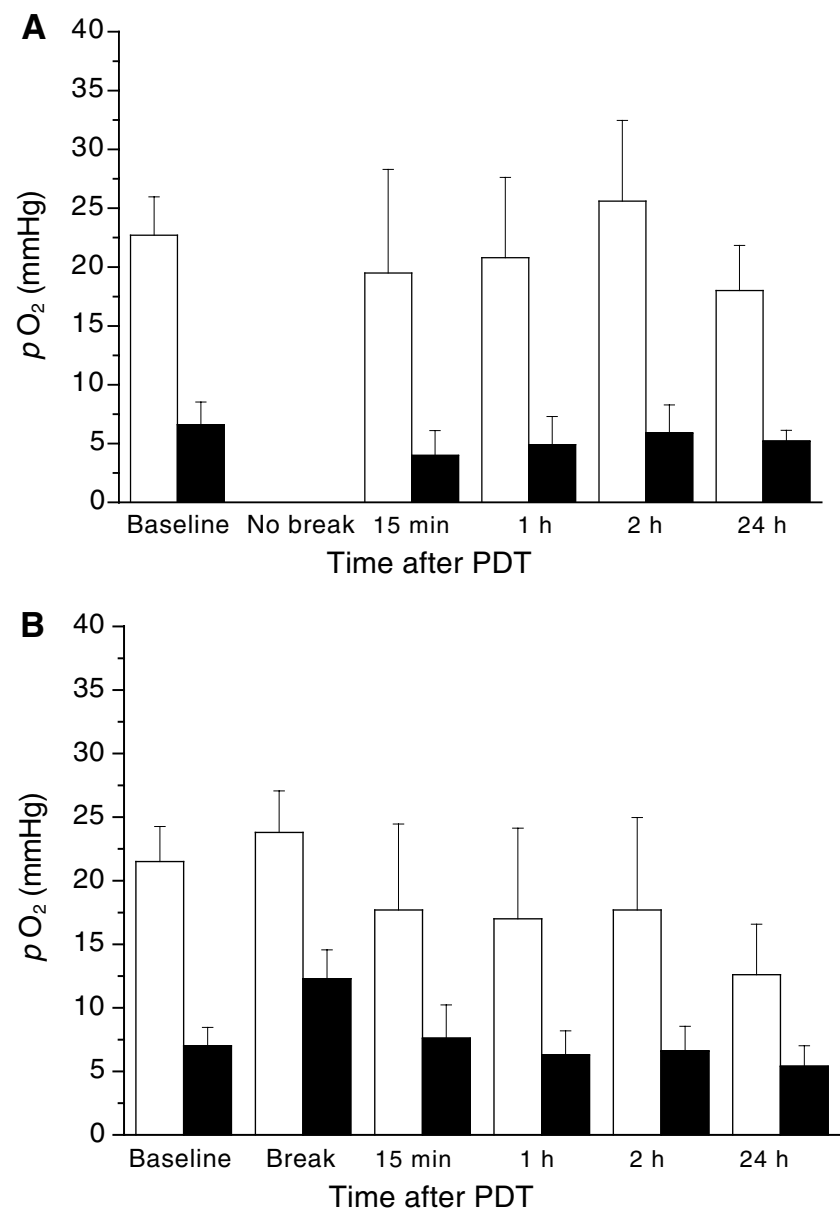

Figure $3 \mathrm{pO}_{2}$ was measured prior to and $15 \mathrm{~min}, \mathrm{I} \mathrm{h}, 2 \mathrm{~h}$ and $24 \mathrm{~h}$ (if fractionated additionally in the light pause) after low-dose PDT $\left(25 \mathrm{~mW} \mathrm{~cm}^{-2}, 100 \mathrm{~J} \mathrm{~cm}^{-2}\right)$ in tumour tissue (a) and in surrounding tissue ( $\square$ ) after continuous $(\mathbf{A}, n=7)$ or fractionated $(\mathbf{B}, n=6)$ irradiation (median \pm s.e.m.).

Continuous irradiation during PDT induced a slight decrease of $\mathrm{pO}_{2}$ in surrounding tissue and in tumour tissue: following PDT, $\mathrm{pO}_{2}$ decreased from $22.7 \pm 3.3 \mathrm{mmHg}$ (baseline) to $19.5 \pm 8.8$ $\mathrm{mmHg}(15 \mathrm{~min})$, followed by a slight increase to $20.8 \pm 6.8 \mathrm{mmHg}$ $(1 \mathrm{~h})$ and to $25.6 \pm 6.8 \mathrm{mmHg}(2 \mathrm{~h})$, followed by a decrease to $18 \pm 3.8 \mathrm{mmHg}(24 \mathrm{~h})$ in surrounding tissue. The slight increase of tissue $\mathrm{pO}_{2}$ in surrounding tissue $2 \mathrm{~h}$ after treatment is because of a hyperaemic reaction. In tumour tissue, $\mathrm{OO}_{2}$ decreased from $6.6 \pm 1.9 \mathrm{mmHg}$ (baseline) to $4.0 \pm 2.0 \mathrm{mmHg}(15 \mathrm{~min}$ ), followed by an increase after $2 \mathrm{~h}$, followed by a decrease to $5.2 \pm 0.9 \mathrm{mmHg}$ (24h) (Figure 3A).

The fractionated irradiation induced a slight decrease of $p \mathrm{O}_{2}$ in surrounding tissue and in tumour tissue as well (Figure 3B). Following PDT, $\mathrm{pO}_{2}$ increased from $21.5 \pm 2.7 \mathrm{mmHg}$ (baseline) to $23.8 \pm 3.2 \mathrm{mmHg}$ (in the irradiation break), decreased to $17.7 \pm 6.7 \mathrm{mmHg}(15 \mathrm{~min} / 2 \mathrm{~h})$ followed by a slight decrease after $24 \mathrm{~h}$ in surrounding tissue. In tumour tissue, $\mathrm{pO}_{2}$ increased from $7.0 \pm 1.5 \mathrm{mmHg}$ (baseline) to $12.3 \pm 2.2 \mathrm{mmHg}$ (in the irradiation break), followed by a decrease to $7.6 \pm 2.6 \mathrm{mmHg}(15 \mathrm{~min})$ and to $6.3 \pm 1.9 \mathrm{mmHg}(1 \mathrm{~h})$, followed by a slight increase to $6.6 \pm 1.9$ $\mathrm{mmHg}(2 \mathrm{~h})$, followed by a slight decrease to $5.4 \pm 1.6 \mathrm{mmHg}(24 \mathrm{~h})$ (Figure 3B).

Remarkable is the fact that the $\mathrm{pO}_{2}$ in the irradiation break increased in tumour and surrounding tissue following fractionated low-dose PDT. On the contrary, following high-dose PDT, the $\mathrm{pO}_{2}$ decreased in the irradiation break in tumour and surrounding tissue (Figures $2 \mathrm{~B}$ and $3 \mathrm{~B}$ ).

\section{Tumour growth curves}

Figure 4 shows the tumour growth curves of the different experimental groups. Prior to PDT, there was no statistical difference of the tumour volume of any of the experimental groups including the control group (I-VI) (Figure 4). Prior to high-dose PDT $\left(100 \mathrm{~mW} \mathrm{~cm}^{-2}, 100 \mathrm{~J} \mathrm{~cm}^{-2}\right.$, groups II and III), the mean volume of the subcutaneously grown tumours was $101 \pm 16 \mathrm{~mm}^{3}$ in group II and $113 \pm 6 \mathrm{~mm}^{3}$ in group III. Group II, treated with continuous high-dose PDT, as well as group III, treated with fractionated high-dose PDT, showed no signs of tumour 3 days after therapy, instead a massive scar formation developed. There was no recurrence up to the end of the observation period. Thus, high-dose PDT induced complete remission of all tumours (13 out of 13) (Table 1). Irradiation either continuous or fractionated did not change the therapeutic outcome in these groups (Figure 4).

Prior to low-dose PDT $\left(25 \mathrm{~mW} \mathrm{~cm}^{-2}, 100 \mathrm{~J} \mathrm{~cm}^{-2}\right.$, groups IV and $\mathrm{V})$, the mean volume of the subcutaneously grown tumours was $97 \pm 5 \mathrm{~mm}^{3}$ in group IV and $101 \pm 7 \mathrm{~mm}^{3}$ in group V. Group IV, treated with continuous low-dose PDT, as well as group V, treated with fractionated low-dose PDT, showed a reduced mean tumour volume at day 3 (group IV: $102 \pm 6 \mathrm{~mm}^{3}$; group V: $108 \pm 8 \mathrm{~mm}^{3}$ ) and day 5 (group IV: $161 \pm 27 \mathrm{~mm}^{3}$; group V: $143 \pm 16 \mathrm{~mm}^{3}$ ) as compared to control group (I) (day 3: $123 \pm 13 \mathrm{~mm}^{3}$; day 5: $254 \pm 60 \mathrm{~mm}^{3}$ ). From day 9 up to the end of the observation period, there was no difference in tumour growth between group IV or group V and the control group (I) detectable (Figure 4). There was no significant difference in tumour growth curves following either continuous or fractionated irradiation (Figure 4). In contrast to high-dose PDT, low-dose PDT resulted in progression of all tumours (13 out of 13), independent of the irradiation protocol (Table 1).

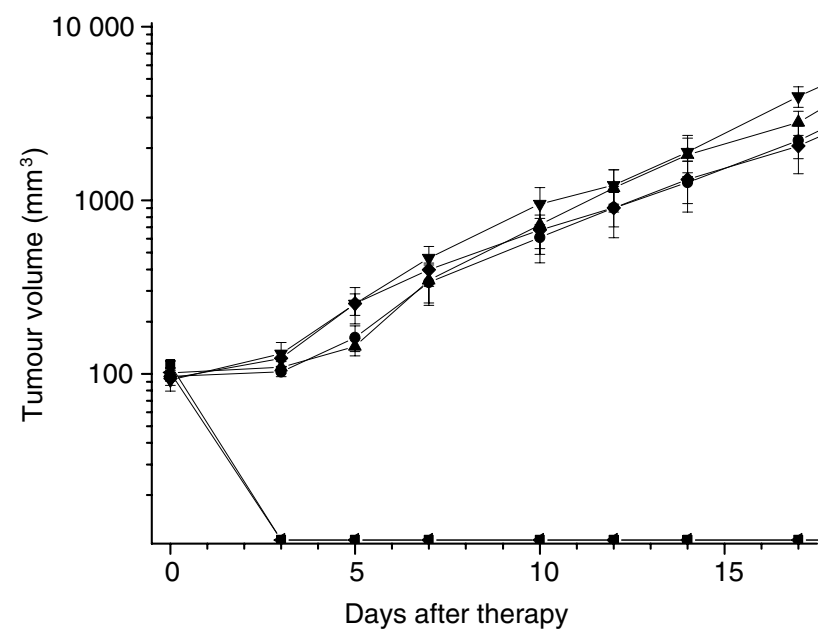

Figure 4 A-Mel-3 amelanotic melanomas were implanted subcutaneously in the dorsal skinfold of Syrian Golden hamsters $(n=38)$. At $150 \mathrm{~min}$ after i.v. ALA application $\left(500 \mathrm{mg} \mathrm{kg}^{-1}\right.$ b.w.) irradiation was performed. Six groups were formed according to the protocols: $(\downarrow)$ control (I, $n=6) ;(4)$ high-dose PDT $\left(100 \mathrm{~mW} \mathrm{~cm}^{-2}, 100 \mathrm{~J} \mathrm{~cm}^{-2}\right.$ ) continuous irradiation (II, $n=7)$; ( $)$ high-dose PDT $\left(100 \mathrm{~mW} \mathrm{~cm}^{-2}\right.$ $\left.100 \mathrm{Jm}^{-2}\right)$, fractionated irradiation $(I I I, n=6) ;(0)$ low-dose PDT $\left(25 \mathrm{~mW} \mathrm{~cm}^{-2}, 100 \mathrm{~cm}^{-2}\right)$, continuous irradiation (IV, $\left.n=7\right) ;(\boldsymbol{\Lambda})$ lowdose PDT $\left(25 \mathrm{~mW} \mathrm{~cm}^{-2}, 100 \mathrm{~cm}^{-2}\right)$, fractionated irradiation $(V, n=6)$ (V) low-dose PDT $\left(25 \mathrm{~mW} \mathrm{~cm}^{-2}, 100 \mathrm{~J} \mathrm{~cm}^{-2}\right)$, continuous irradiation without ALA $(\mathrm{VI}, n=6)]$. Tumour volumes were recorded throughout the complete observation period (28 days) (median \pm s.e.m.). 
Table I Complete remission of all tumours induced by high-dose PDT

\begin{tabular}{|c|c|c|c|c|c|c|c|}
\hline Groups & ALA (mg kg ${ }^{-1}$ b.w.) & Light intensity $\left(\mathrm{mW} \mathrm{cm} \mathrm{cm}^{-2}\right)$ & Irradiation & Complete remission & Partial remission & No change & Progression \\
\hline 1 & - & - & - & $0 / 6$ & $0 / 6$ & $0 / 6$ & $6 / 6$ \\
\hline ॥ & 500 & 100 & Continuous & 7/7 & $0 / 7$ & $0 / 7$ & $0 / 7$ \\
\hline III & 500 & 100 & Fractionated & $6 / 6$ & $0 / 6$ & $0 / 6$ & $0 / 6$ \\
\hline$\vee$ & 500 & 25 & Fractionated & $0 / 6$ & $0 / 6$ & $0 / 6$ & $6 / 6$ \\
\hline $\mathrm{VI}$ & - & 25 & Continuous & $0 / 6$ & $0 / 6$ & $0 / 6$ & $6 / 6$ \\
\hline
\end{tabular}

PDT = photodynamic therapy. Data represent the therapeutic outcome after 28 days of a subcutaneously implanted amelanotic malignant melanoma (A-Mel-3) in Syrian Golden hamsters following PDT with 5-ALA i.v. (500 $\mathrm{mg} \mathrm{kg}^{-1}$ b.w.) and irradiation (fluence: $100 \mathrm{~J} \mathrm{~cm}^{-2}$ ) I50 min thereafter using incoherent light source and different dosimetric parameters.

Prior to continuous low-dose PDT without ALA $\left(25 \mathrm{~mW} \mathrm{~cm}^{-2}\right.$, group VI), the mean volume of the subcutaneously grown tumours was $92 \pm 12.5 \mathrm{~mm}^{3}$. During the whole observation period, there was no significant difference in tumour growth between group VI and the control group (I) (Figure 4). The tumour growth curve showed an exponential trend. Low-dose PDT without ALA resulted in progression of all tumours (six out of six) (Table 1).

The subcutaneously grown tumours of the control group (I) showed a mean tumour volume of $94 \pm 3.4 \mathrm{~mm}^{3}$ at the beginning of the observation period. The tumour growth curves showed an exponential growth (Figure 4). All tumours showed progression (six out of six) (Table 1).

\section{DISCUSSION}

This study shows that only high-dose PDT $\left(100 \mathrm{~mW} \mathrm{~cm}^{-2}\right.$; $100 \mathrm{~J} \mathrm{~cm}^{-2}$ ) with ALA results in a significant decrease of $\mathrm{pO}_{2} 24 \mathrm{~h}$ after PDT as compared to low-dose PDT $\left(25 \mathrm{~mW} \mathrm{~cm}^{-2}, 100 \mathrm{~J} \mathrm{~cm}^{-2}\right)$ (Figures 2 and 3 ). Fractionation of PDT did not show any effect regarding the $\mathrm{pO}_{2}$ in tumour tissue. However, following fractionated irradiation, the $\mathrm{OO}_{2}$ in surrounding tissue decreased to a significant lower value $24 \mathrm{~h}$ after either high-dose or low-dose PDT as compared to tumour tissue (Figures 2 and 3 ).

Only high-dose PDT induced complete remission of all tumours (13 out of 13). Neither continuous nor fractionated irradiation did change the therapeutic outcome after high-dose or low-dose PDT (Figure 4).

The dorsal skinfold chamber model was used in the present study because this tumour model is well established to investigate the microcirculatory effects on tumour and normal tissue following different therapeutic approaches (Dellian et al, 1995; Schacht et al, 2001). In addition, measuring the tumour volume of the subcutaneously implanted amelanotic melanoma after PDT has been studied as well to evaluate the efficacy of different anticancer treatments (Weiss et al, 1990; Szeimies et al, 1995; Dellian et al, 1996; Abels et al, 1997a, b).

Photodynamic therapy was performed according to previous studies (Abels et al, 1994, 1997a; Szeimies et al, 1995). Since in the literature it is reported that low-dose PDT or fractionated irradiation may be more effective as compared to high-dose PDT or continuous irradiation (Gibson et al, 1990; Messmann et al, 1995; de Bruijn et al, 1999; Iinuma et al, 1999), PDT dosimetry was performed with a light intensity of either 100 or $25 \mathrm{~mW} \mathrm{~cm}^{-2}$ and light was applied either continuously or fractionated according to the experiments of Curnow et al (2000) and de Bruijn et al (1999).

The efficacy of ALA - PDT was evaluated by measuring the tissue $\mathrm{pO}_{2}$ (Blumenroder et al, 1997; Hartmann et al, 1997; Curnow et al, 2000; Niedre et al, 2002) since tissue $p_{2}$ correlates with a functional microcirculation (Vaupel, 1994). The technique of measuring the tissue $\mathrm{pO}_{2}$ by luminescence lifetime imaging using planar oxygen sensors allows a spatially highly resolved and time-resolved mapping of two-dimensional $\mathrm{pO}_{2}$-distribution within the entire chamber tissue in a noninvasive way (Liebsch et al, 2000, 2001).
Thus, two independent parameters to assess PDT efficacy were determined: the tissue $p \mathrm{O}_{2}$ can be considered as a short-term parameter (up to $24 \mathrm{~h}$ after PDT), whereas the tumour growth curves represent the long-term parameter (up to 28 days after PDT).

In Figure $2 \mathrm{~A}$ and $\mathrm{B}, \mathrm{O}_{2}$ in tumour and surrounding tissue decreases up to $24 \mathrm{~h}$ following continuous or fractionated highdose PDT. This result is in agreement with the literature. Mcllroy et al (1998) described a 10-fold decrease of the oxygen level in normal rat liver following PDT with ALA $(100 \mathrm{~mW}, 60 \mathrm{~J})$ (McIlroy et al, 1998). The decline of $\mathrm{pO}_{2}$ following PDT could be caused by photochemical consumption of molecular oxygen (Busch et al, 2000) or by the lack of oxygen supply caused by massive microvascular damage following high-dose PDT (Castellani et al, 1963; Vaupel et al, 1977, 1981, 1989). The fragile microvasculature of experimental and human solid tumours is characterised already in very early growth stages by structural and functional abnormalities (Vaupel et al, 1989). The structural abnormalities can result in deficient endothelial lining or basement membrane, in loss of vessel hierarchy or in heterogeneous vascularisation, whereas the functional abnormalities can lead to an increased vascular fragility, to an increase of viscous resistance with microand macrothrombosis or to an increased interstitial fluid pressure (Ribbert, 1904; Vaupel et al, 1989). These specific characteristics make the microvasculature of experimental and human solid tumours very vulnerable for any treatment targeting the microvasculature, like PDT.

In contrast to other investigations, fractionation of the light dose $\left(20 \mathrm{~J} \mathrm{~cm}^{-2}, 15 \mathrm{~min}, 80 \mathrm{~J} \mathrm{~cm}^{-2}\right)$ did not further decrease $\mathrm{pO}_{2}$ in tumour tissue in the present study. However, in surrounding tissue a further reduction of $\mathrm{pO}_{2} 24 \mathrm{~h}$ after PDT is shown (Figure 2B). Curnow et al (2000) described using the polarographic Eppendorf $\mathrm{pO}_{2}$ histograph system in three animals also a benefit of fractionation $(5 \mathrm{~J}, 150 \mathrm{~s}, 20 \mathrm{~J})$ of PDT with ALA $\left(200 \mathrm{mg} \mathrm{kg}^{-1}\right)$ in the normal rat colon. They measured a greater decrease of $p \mathrm{O}_{2}$ and a greater area of necrosis following fractionated irradiation. However, they did not perform any measurements in tumour tissue. Despite the fact that the Eppendorf $p \mathrm{O}_{2}$ histograph is considered to be the gold standard for measuring $p \mathrm{O}_{2}$ in tissue (Nozue et al, 1996), it does not allow a spatially and highly timeresolved measurement of the $\mathrm{pO}_{2}$-value as compared with the method used in this study. Curnow et al were not able to accurately ascertain in which tissue layer the polarographic Eppendorf needle is located during measurements. Moreover, they did perform the measurements only at one site per animal. According to the extensive investigations by Vaupel (Vaupel et al, 1977, 1981, 1989) measuring just at one point does not represent the entire tissue (Lord and Paoni, 2001). Besides this, the mechanical pressure exerted by placing the needle in the tissue can easily irritate the membrane and therefore change the diffusion capacity of the membrane. The used technique against the background of measuring the $\mathrm{pO}_{2}$ just in normal tissue and not in tumour tissue makes this study incomparable to the results of our study as described above. Most probably if the study had focused on tumour tissue they would have obtained similar results. 
Using $\mathrm{pO}_{2}$-electrodes, Pogue et al (2001) could show in the rat R3230Ac mammary adenocarcinoma after fractionated PDT with Verteporfin ${ }^{\circledR}$ directly after completion of the irradiation a heterogeneous reduction of tissue $\mathrm{pO}_{2}$, but not complete anoxia. Unfortunately, measurements in surrounding normal tissue were not taken. Nevertheless, using laser Doppler measurements in the same experiments, a significant reduction of blood flow during the initial phase of irradiation could be shown (Pogue et al, 2001).

Measuring the diameter of necrosis in tumour and normal tissue following mTHPC-mediated PDT, Tsutsui et al (2002) showed a significant enhancement of necrosis produced only in normal tissue and not in tumour tissue following fractionated irradiation with $100 \mathrm{~mW}$. This finding supports our result showing that if an efficient PDT is performed, a fast breakdown of the microcirculation in tumours occurs preventing an additional benefit of fractionated irradiation in tumour tissue, but not in the surrounding tissue with a less fragile microvascular system, which is still functioning, thus supplying oxygen (Djavaheri-Mergny et al, 2001; Lord and Paoni, 2001).

Following low-dose PDT $\left(25 \mathrm{~mW} \mathrm{~cm}^{-2}, 100 \mathrm{~J} \mathrm{~cm}^{-2}\right)$ and continuous irradiation, a slight but not significant reduction of tissue $\mathrm{pO}_{2}$ can be observed $24 \mathrm{~h}$ after treatment in this model (Figure $3 \mathrm{~A}$ ). Since high-dose PDT with continuous irradiation resulted in $100 \%$ complete remission (Figure 4), this dosimetry protocol, not inducing complete remission, was chosen to demonstrate a benefit by using fractionated irradiation. As expected, an increase of tissue $\mathrm{pO}_{2}$ in surrounding tissue ( $111 \%$ of baseline) and an even more pronounced increase in tumour tissue (176\% of baseline) could be measured during the irradiation break (Figure 3B). Nevertheless, $24 \mathrm{~h}$ after irradiation there is a higher relative decrease of $\mathrm{pO}_{2}$ in surrounding tissue (58.6\% of baseline) as compared to tumour tissue (77.1\% of baseline). The increase of tissue $\mathrm{pO}_{2}$ in tumour and surrounding tissue during the irradiation break can be explained by a reduced cellular respiration break by functioning oxygen supply. This assumption is supported by the fact that ALA is primarily metabolised to porphyrins in the tumour parenchyma (Fritsch et al, 1997). Therefore, direct tumour cell toxicity by PDT with ALA is expected. Further evidence is given by measurements of NADH fluorescence to assess acute cellular PDT-induced damage in vivo, showing a significant reduction directly after the first fraction of irradiation using Verteporfin ${ }^{\circledR}$ as photosensitiser (Pogue et al, 2001). Comparing continuous $v s$ fractionated irradiation for lowdose PDT, no difference can be measured regarding $\mathrm{pO}_{2} 24 \mathrm{~h}$ after treatment in tumour tissue, but as for high-dose PDT only in the surrounding tissue, difference can be measured.

The tumour growth curves (Figure 4) show a completely different development comparing high-dose PDT (groups II and III) with low-dose PDT (groups IV and V). There was no difference following high-dose PDT regarding continuous or fractionated irradiation, because continuous irradiation induced disappearance of all signs of tumour 3 days after therapy. Thus, any benefit of fractionated irradiation would have been masked. According to previous results using this model (Szeimies et al, 1995; Abels et al, 1997), the development of the tumour growth curves after highdose PDT was unexpected, because in these experiments PDT using the same parameters and continuous irradiation yielded only one complete remission out of six subcutaneously implanted amelanotic melanomas. The only experimental difference is the use of an argon-pumped dye laser tuned to $635 \mathrm{~nm}$ for irradiation, while in the present investigation an incoherent light source $(\lambda=580-740 \mathrm{~nm})$ was employed. Since significant amounts of additional porphyrins, besides PpIX, are formed in this model following systemic application of ALA (Fritsch et al, 1997) absorbing beyond $635 \mathrm{~nm}$; the wavelength range of the incoherent light source covers their absorption spectrum, thus leading to a more pronounced photodynamic effect.

In contrast, low-dose PDT with either continuous or fractionated irradiation shows just a transient and small delay of tumour growth at days 3-7 as compared to the control group (Figure 4). Moreover, at day 5 there might be a nonsignificant difference visible between continuous $\left(162 \pm 27 \mathrm{~mm}^{3}\right)$ or fractionated irradiation $\left(143 \pm 17 \mathrm{~mm}^{3}\right)$, showing the influence of the significant reduction of $\mathrm{pO}_{2}$ in the surrounding tissue after $24 \mathrm{~h}$ by fractionated low-dose PDT (Figure 3B).

These results regarding the efficacy of low-dose $v s$ high-dose PDT with ALA are supported by the findings of Iinuma et al (1999), which could demonstrate a 2-log cell kill and a 3-log cell kill for ALA - PDT with either 30 or $100 \mathrm{~mW} \mathrm{~cm}^{-2}$, respectively, in a rat tumour model in vivo.

In contrast, Tsutsui et al (2002) found a low-dose PDT to be more effective by measuring the depth of necrosis in tumour tissue following mTHPC-mediated PDT. They documented that depth of necrosis following continuous PDT with a low light intensity $(5 \mathrm{~mW})$ is significantly larger as compared to PDT with a high light intensity $(100 \mathrm{~mW})$ from 2.5 to $30 \mathrm{~J}$ total light energy. However, they did not perform an irradiation with a high light dose of $100 \mathrm{~J} \mathrm{~cm}^{-2}$ as carried out in this study.

A $100 \%$ complete remission (13 out of 13 ) was achieved following high-dose PDT $\left(100 \mathrm{~mW} \mathrm{~cm}^{-2}, 100 \mathrm{~J} \mathrm{~cm}^{-2}\right)$ (Table 1). Both irradiation schemes, continuous and fractionated, turned out to be exactly equivalent concerning the therapeutic efficacy in this model. In contrast, no complete remission was observed after lowdose PDT and this is also independent of the irradiation scheme. Therefore, these results do not support the hypothesis that lower PDT fluence rates are associated with increased efficiency of tumour response (Sitnik and Henderson, 1998). Surprisingly, in this study no complete remission of the radiation induced fibro sarcoma (RIF) tumour was obtained using Photofrin ${ }^{\circledR}\left(5 \mathrm{mg} \mathrm{kg}^{-1}\right)$ and high-dose PDT $\left(150 \mathrm{~mW} \mathrm{~cm}^{-2}, 100 \mathrm{~J} \mathrm{~cm}^{-2}\right)$, whereas in our model using these parameters and Photofrin ${ }^{\circledR}$ in five out of six tumours a complete remission is achieved (Dellian et al, 1996).

In conclusion, measuring tissue $\mathrm{pO}_{2}$ by means of luminescence lifetime imaging proves to be a helpful tool to evaluate the acute effects of PDT on the microcirculation. Only high-dose PDT with a high light intensity and a high light dose induces complete remission in our model. Moreover, it could be shown that fractionating the light dose enhances the effect of PDT only in surrounding but not in tumour tissue, since oxygen supply in tumour tissue is already maximal because of the characteristic structural and functional abnormalities of the tumour microvasculature. In addition, no significant effect of fractionated irradiation was shown in our tumour model regarding the therapeutic efficacy 28 days after PDT. The $\mathrm{pO}_{2}$-measurements correlate with the measurements of the tumour volume, only PDT inducing a significant reduction of $\mathrm{pO}_{2}$ in tumour as well as normal tissue $24 \mathrm{~h}$ after PDT resulted in complete remission of tumours 28 days after PDT.

Thus, performing a fractionated PDT with ALA or reducing the light intensity and increasing irradiation time seems not successful in clinical PDT according to the present data.

\section{REFERENCES}

Abels C, Fritsch C, Bolsen K, Szeimies RM, Ruzicka T, Goerz G, Goetz AE (1997a) Photodynamic therapy with 5-aminolaevulinic acid-induced porphyrins of an amelanotic melanoma in vivo. J Photochem Photobiol B 40: $76-83$
Abels C, Heil P, Dellian M, Kuhnle GE, Baumgartner R, Goetz AE (1994) In vivo kinetics and spectra of 5-aminolaevulinic acid-induced fluorescence in an amelanotic melanoma of the hamster. $\mathrm{Br} J$ Cancer 70: $826-833$ 
Abels C, Szeimies RM, Steinbach P, Richert C, Goetz AE (1997b) Targeting of the tumor microcirculation by photodynamic therapy with a synthetic porphycene. J Photochem Photobiol B 40: 305-312

Ackermann G, Abels C, Baumler W, Langer S, Landthaler M, Lang EW, Szeimies RM (1998) Simulations on the selectivity of 5-aminolaevulinic acid-induced fluorescence in vivo. J Photochem Photobiol B 47: 121-128

Blumenroder S, Augustin AJ, Koch FH (1997) The influence of intraocular pressure and systemic oxygen tension on the intravascular $p \mathrm{O}_{2}$ of the pig retina as measured with phosphorescence imaging. Surv Ophthalmol 42 (Suppl 1): S118-S126

Busch TM, Hahn SM, Evans SM, Koch CJ (2000) Depletion of tumor oxygenation during photodynamic therapy: detection by the hypoxia marker EF3 [2-(2-nitroimidazol-1[H]-yl)-N-(3,3,3-trifluoropropyl)acetamide]. Cancer Res 60: 2636-2642

Castellani A, Pace GP, Concioli M (1963) Photodynamic effect of haematoporphyrin on blood microcirculation. J Pathol Bacteriol 86: $99-103$

Curnow A, Haller JC, Bown SG (2000) Oxygen monitoring during 5aminolaevulinic acid induced photodynamic therapy in normal rat colon. Comparison of continuous and fractionated light regimes. J Photochem Photobiol B 58: 149-155

de Bruijn HS, van der Veen N, Robinson DJ, Star WM (1999) Improvement of systemic 5-aminolevulinic acid-based photodynamic therapy in vivo using light fractionation with a 75-minute interval. Cancer Res 59: $901-$ 904

Dellian M, Abels C, Kuhnle GE, Goetz AE (1995) Effects of photodynamic therapy on leucocyte-endothelium interaction: differences between normal and tumour tissue. Br J Cancer 72: 1125-1130

Dellian M, Helmlinger G, Yuan F, Jain RK (1996) Fluorescence ratio imaging of interstitial $\mathrm{pH}$ in solid tumours: effect of glucose on spatial and temporal gradients. Br J Cancer 74: 1206-1215

Djavaheri-Mergny M, Marsac C, Maziere C, Santus R, Michel L, Dubertret L, Maziere JC (2001) UV-A irradiation induces a decrease in the mitochondrial respiratory activity of human NCTC 2544 keratinocytes. Free Radic Res 34: 583-594

Dougherty TJ, Gomer CJ, Henderson BW, Jori G, Kessel D, Korbelik M, Moan J, Peng Q (1998) Photodynamic therapy. J Natl Cancer Inst 90: $889-905$

Edwards SR, Shanley BC, Reynoldson JA (1984) Neuropharmacology of delta-aminolaevulinic acid - I. Effect of acute administration in rodents. Neuropharmacology 23: 477-481

Endrich B, Asaishi K, Gotz A, Messmer K (1980) Technical report - a new chamber technique for microvascular studies in unanesthetized hamsters. Res Exp Med 177: $125-134$

Fortner JG, Mahy AG, Schrodt GR (1961) Transplantable tumors of the Syrian (Golden) Hamsters. I. Tumors of the alimentary tract, endocrine glands and melanomas. Cancer Res 21: 161-198

Fritsch C, Batz J, Bolsen K, Schulte KW, Zumdick M, Ruzicka T, Goerz G (1997) Ex vivo application of delta-aminolevulinic acid induces high and specific porphyrin levels in human skin tumors: possible basis for selective photodynamic therapy. Photochem Photobiol 66: $114-118$

Gibson SL, VanDerMeid KR, Murant RS, Raubertas RF, Hilf R (1990) Effects of various photoradiation regimens on the antitumor efficacy of photodynamic therapy for R3230AC mammary carcinomas. Cancer Res 50: $7236-7241$

Grant WE, Hopper C, MacRobert AJ, Speight PM, Bown SG (1993) Photodynamic therapy of oral cancer: photosensitisation with systemic aminolaevulinic acid. Lancet 342: 147-148

Hartmann P, Ziegler W, Lubbers DW (1997) Fluorescence lifetime imaging of the skin PO2 supply. Instrumentation and results. Adv Exp Med Biol 428: $605-611$

Hua Z, Gibson SL, Foster TH, Hilf R (1995) Effectiveness of deltaaminolevulinic acid-induced protoporphyrin as a photosensitiser for photodynamic therapy in vivo. Cancer Res 55: 1723-1731

Iinuma S, Schomacker KT, Wagnieres G, Rajadhyaksha M, Bamberg M, Momma T, Hasan T (1999) In vivo fluence rate and fractionation effects on tumor response and photobleaching: photodynamic therapy with two photosensitisers in an orthotopic rat tumor model. Cancer Res 59: 61646170

Kriegmair M, Stepp H, Steinbach P, Lumper W, Ehsan A, Stepp HG, Rick K, Knuchel R, Baumgartner R, Hofstetter A (1995) Fluorescence cystoscopy following intravesical instillation of 5-aminolevulinic acid: a new procedure with high sensitivity for detection of hardly visible urothelial neoplasias. Urol Int 55: 190-196
Langer S, Abels C, Botzlar A, Pahernik S, Rick K, Szeimies RM, Goetz AE (1999) Active and higher intracellular uptake of 5-aminolevulinic acid in tumors may be inhibited by glycine. J Invest Dermatol 112: 723-728

Liebsch G, Klimant I, Frank B, Holst G, Wolfbeis OS (2000) Luminescence lifetime imaging of oxygen $\mathrm{pH}$ and carbon dioxide distribution using optical sensors. Appl Spectrosc 54: 548

Liebsch G, Klimant I, Krause C, Wolfbeis OS (2001) Fluorescent imaging of $\mathrm{pH}$ with optical sensors using time domain dual lifetime referencing. Anal Chem 73: $4354-4363$

Livingston RB, Carter SK (1982) Experimental design and clinical trials: clinical perspectives. In Principles of Cancer Treatment, Carter SK, Glatstein SK, Livingston RB (eds). New York: McGraw-Hill

Lord E, Paoni S (2001) Effects of radiation on tumor intravascular oxygenation, vascular configuration, development of hypoxia, and clonogenic survival. Radiat Res 155: $360-368$

McIlroy BW, Curnow A, Buonaccorsi G, Scott MA, Bown SG, MacRobert AJ (1998) Spatial measurement of oxygen levels during photodynamic therapy using time-resolved optical spectroscopy. J Photochem Photobiol B 43: $47-55$

Messmann H, Mlkvy P, Buonaccorsi G, Davies CL, MacRobert AJ, Bown SG (1995) Enhancement of photodynamic therapy with 5-aminolaevulinic acid-induced porphyrin photosensitisation in normal rat colon by threshold and light fractionation studies. Br J Cancer 72: 589-594

Mlkvy P, Messmann H, Regula J, Conio M, Pauer M, Millson CE, MacRobert AJ, Bown SG (1995) Sensitization and photodynamic therapy (PDT) of gastrointestinal tumors with 5-aminolaevulinic acid (ALA) induced protoporphyrin IX (PPIX). A pilot study. Neoplasma 42: 109113

Niedre M, Patterson MS, Wilson BC (2002) Direct near-infrared luminescence detection of singlet oxygen generated by photodynamic therapy in cells in vitro and tissues in vivo. Photochem Photobiol 75: $382-391$

Nozue M, Lee I, Manning JM, Manning LR, Jain RK (1996) Oxygenation in tumors by modified hemoglobins. J Surg Oncol 62: 109-114

Pass HI (1993) Photodynamic therapy in oncology: mechanisms and clinical use. J Natl Cancer Inst 85: 443-456

Peng Q, Warloe T, Berg K, Moan J, Kongshaug M, Giercksky KE, Nesland JM (1997) 5-Aminolevulinic acid-based photodynamic therapy. Clinical research and future challenges. Cancer 79: 2282-2308

Pogue BW, Braun RD, Lanzen JL, Erickson C, Dewhirst MW (2001) Analysis of the heterogeneity of $\mathrm{pO}_{2}$ dynamics during photodynamic therapy with verteporfin. Photochem Photobiol 74: 700-706

Ribbert H (1904) Über das Gefäßsystem und die Heilbarkeit der Geschwülste. Dtsch Med Wochensch 29: 113-115

Rittenhouse-Diakun K, Van Leengoed H, Morgan J, Hryhorenko E, Paszkiewicz G, Whitaker JE, Oseroff AR (1995) The role of transferrin receptor (CD71) in photodynamic therapy of activated and malignant lymphocytes using the heme precursor delta-aminolevulinic acid (ALA). Photochem Photobiol 61: 523-528

Robinson DJ, de Bruijn HS, de Wolf WJ, Sterenborg HJ, Star WM (2000) Topical 5-aminolevulinic acid-photodynamic therapy of hairless mouse skin using two-fold illumination schemes: PpIX fluorescence kinetics, photobleaching and biological effect. Photochem Photobiol 72: 794-802

Schacht V, Becker K, Landthaler M, Szeimies RM, Abels C (2001) Apoptosis and leucocyte - endothelium interactions contribue to the delayed effects of cryotherapy on solid tumors in vivo. Arch Dermatol Res 294: 341-348

Sitnik TM, Henderson BW (1998) The effect of fluence rate on tumor and normal tissue responses to photodynamic therapy. Photochem Photobiol 67: $462-466$

Szeimies RM, Abels C, Fritsch C, Karrer S, Steinbach P, Baumler W, Goerz G, Goetz AE, Landthaler M (1995) Wavelength dependency of photodynamic effects after sensitization with 5 -aminolevulinic acid in vitro and in vivo. J Invest Dermatol 105: 672-677

Szeimies RM, Sassy T, Landthaler M (1994) Penetration potency of topical applied delta-aminolevulinic acid for photodynamic therapy of basal cell carcinoma. Photochem Photobiol 59: 73-76

Tomayko MM, Reynolds CP (1989) Determination of subcutaneous tumor size in athymic (nude) mice. Cancer Chemother Pharmacol 24: 148-154

Tsutsui H, MacRobert AJ, Curnow A, Rogowska A, Buonaccorsi G, Kato H, Bown SG (2002) Optimisation of illumination for photodynamic therapy with $\mathrm{mTHPC}$ on normal colon and a transplantable tumour in rats. Lasers Med Sci 17: 101-109

van Hillegersberg R, Kort WJ, Wilson JH (1994) Current status of photodynamic therapy in oncology. Drugs 48: $510-527$

Vaupel P (1977) Hypoxia in neoplastic tissue. Microvasc Res 13: 399-408 
ALA - PDT following different dosimetric protocols

$P$ Babilas et al

Vaupel P (1994) Blood Flow, Oxygenation, Tissue pH Distribution, and Bioenergetic Status of Tumors, p 23. Berlin, Germany: Ernst Schering Research Foundation

Vaupel P, Kallinowski F, Okunieff P (1989) Blood flow, oxygen and nutrient supply, and metabolic microenvironment of human tumors: a review. Cancer Res 49: 6449-6465

Vaupel PW, Frinak S, Bicher HI (1981) Heterogeneous oxygen partial pressure and $\mathrm{pH}$ distribution in $\mathrm{C} 3 \mathrm{H}$ mouse mammary adenocarcinoma. Cancer Res 41: 2008-2013
Weiss N, Delius M, Gambihler S, Dirschedl P, Goetz A, Brendel W (1990) Influence of the shock wave application mode on the growth of A-Mel 3 and SSK2 tumors in vivo. Ultrasound Med Biol 16: 595-605

Williams WJE (1990) Hematology, 4th edn. New York: McGraw-Hill Workman P, Balmain A, Hickman JA, McNally NJ, Rohas AM, Mitchison NA, Pierrepoint CG, Raymond R, Rowlatt C, Stephens TC et al (1988) UKCCCR guidelines for the welfare of animals in experimental neoplasia. Lab Anim 22: 195-201 